悪性腫瘍が疑われた上顎洞炎症性偽腫瘍例

中川 崇・服部 賢二・岩田 伸子
星野 隆英・佐々木 知

\title{
A Case of Inflammatory Pseudotumor in the Maxillary Sinus Mimicking Malignancy
}

\author{
Takashi Nakagawa, Kenji Hattori, Nobuko Iwata, \\ Takahide Hoshino and Tomo Sasaki \\ (Sumitomo Hospital)
}

\begin{abstract}
Inflammatory pseudotumor is a benign chronic non-specific granulation consisting of fibroblasts, histiocytes, plasma cells and inflammatory cells. It forms a space-occupying, rounded mass, appearing in various locations, but its occurrence in the paranasal sinus is rare. We report a 63-yeas old man with inflammatory pseudotumor in the maxillary sinus. Histopathological diagnosis of inflammatory pseudotumor is difficult, and differential diagnosis from malignant tumor is often a concern for otolaryngologists and pathologists. Indeed our case also resembled malignant tumor, especially nasal NK/T cell lymphoma. In this report, we discussed the clinicopathological features of inflammatory pseudotumor and reviewed the pertinent literature.

The patient presented a left lacrimation and exophthalmos at the initial medical examination. The findings of computer tomography (CT) and magnetic resonance image (MRI) strongly suggested malignant tumor of the maxillary sinus. To establish a histopathological diagnosis, biopsy was performed by nasal endoscopy. Surprisingly, there were no tumor cells seen in the biopsy specimen, and the diagnosis was inflammatory pseudotumor. Seven days later, radical surgery was performed, and the mass was resected completely. Three months after the initial surgery, recurrence in the maxillary sinus was confirmed. The second procedure was carried out, but total removal of the mass could not be achieved. After surgery, local corticoid steroid injections were repeated by administered over a one-week period. However, one year after the last surgery, the mass started to re-grow. A third procedure was performed for volume reduction with a KTP laser. Five months have passed since the third surgery and there has been no change observed in the size of the mass.
\end{abstract}

Key words : inflammatory pseudotumor, paranasal sinus, histopathological diagnosis, operation, local corticoid steroid injections

はじめに

炎症性偽腫瘍とは病理学的には線維芽細胞の増生を背 景に, リンパ球，形質細胞の強い浸潤を伴った非腫瘍性 の慢性炎症性肉芽であるが, 臨床的には腫瘍性に発育し, 腫瘤を形成することから真の腫瘍との鑑別が困難である
とされている，好発部位は肺, 眼窩内であり, 副鼻腔で の発生はまれである. 今回われわれは，上顎洞内に発生 した炎症性偽腫瘍を経験し，またその診断にあたっては 悪性腫瘍との鑑別に苦慮したことから，若干の文献的考 察を加えて報告する。 


\section{症例}

症例：63 歳, 男性。

主訴: 左眼球突出, 流涙。

既往歴：23 歳頃交通事故にて頭部，顔面打撲。30 歳 頃に鼻苜摘出術 (左右不明)。平成 11 年 7 月, 近医歯科 にて左上顎 $5 \sim 7$ 拔歯.

合併症：気管支喘息にてプレドニン $5 \mathrm{mg} /$ 日内服中.

現病歴：平成 11 年 8 月頃より左流涙を自覚するも放 置, 平成 12 年 3 月頃より左眼球突出に気づき，また左流 涙む増加してきたことから当院眼科を受診した。眼科に て副鼻腔単純 CT を撮影したところ, 左上顎洞〜眼窩に 至る腫瘤を認め, 上顎洞腫瘍の疑いのため平成 12 年 3 月 24 日当科を紹介され初診した。

現症：初診時に左眼球突出，流涙，内転障害を認めた。 しかし視力障害, 視野障害などはなかった。また鼻内所 見では腫瘤によると思われる上顎洞自然口付近の粘膜膨 隆を認めるも, 肉眼的には表面粘膜は正常であり鼻出血, 鼻汁も認めなかった。頸部リンパ節腫脹もなく, その他 の耳鼻咽喉科学的局所所見および全身理学的所見には異 常を認めなかった。

検查所見：副鼻腔 CT では骨破壊を伴いながら左上顎 洞加ら眼窩内, 篩骨洞へと至る巨大な腫瘤陰影を認めた。 造影により腫瘤は内部不均一に造影され，充実性の腫瘍 を疑わせる所見であった。眼窩下壁，上澦洞内側壁の骨
は腫瘤により破壊されており，また下直筋は腫瘤により 確認できなかった（図1）。

MRI では腫瘤は T1 強調画像にてほぼ均一な低信号を 示し，T2 強調画像にて不均一な等〜高信号を呈してい た。ガドリニウム造影では内部不均一に造影されており， 腫瘤が下直筋，視神経を圧排している像がみられた。 T2 強調画像では眼窩底〜上顎洞内壁にやや不明瞭な低信号 領域が存在しており骨膜が存在していることを示唆して いた。また篩骨蜂巣には慢性副鼻腔炎を疑わせる所見は あるが，腫瘤の進展はないものと考光られた（図 2)。

血液・尿検查では特に異常はなく, 腎機能, 肝機能は ともに正常であった。また血沈, CRP, c-ANCA, p-ANCA, RF，ANA は陰性であった。胸部 X 線も異常はなかったた。

経過：以上のように臨床所見加らは積極的に悪性を疑 ら所見はないものの，画像所見からは悪性腫瘍を否定で きず，上顎洞腫怚の疑いにて平成 12 年 3 月 28 日当科入 院となった。診断目的のため 30 日, 局所麻酔にて内視鏡 下の腫瘍生検術を施行した。上顎洞を開放したところ， 洞内に充満する灰白色の腫瘤を認め(図 3), そこから組 織片を採取し術中迅速病理検查を行った。複数回行った 結果はいずれも腫瘍細胞は認めず，慢性炎症と肉芽のみ であった。このことより悪性腫場の可能性は低いと判断 し, 4 月 6 日に局所麻酔下で上顎洞根本術を施行した。手 術ではすず犬歯窩を切開し上顎骨前壁を露出させた。次

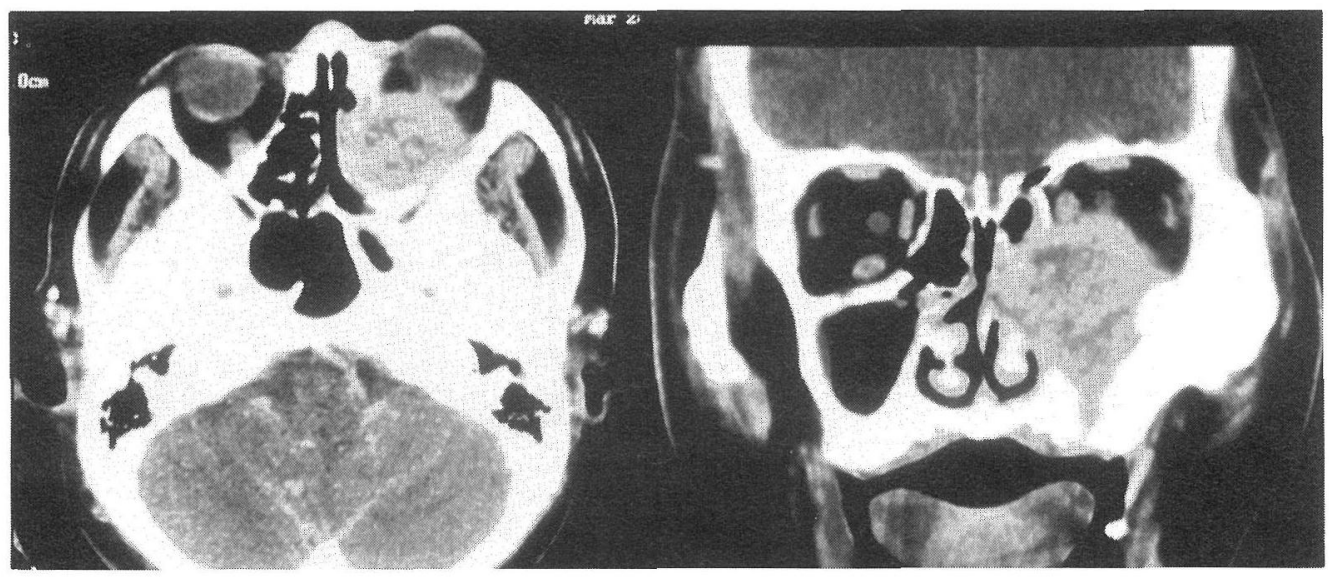

（水平断）

（冠状断）

図 1 造影 CT 所見

左上顎洞から眼窩内，穊骨洞へと至る腫瘤陰影を認める，下直筋は，腫瘤により確認できなかった。 上顎洞下壁から歯根に向けて骨欠損像がみられる。また造影剂により，内部は不均一に造影され，充 実性の腫瘍を疑わせる所見であった。 


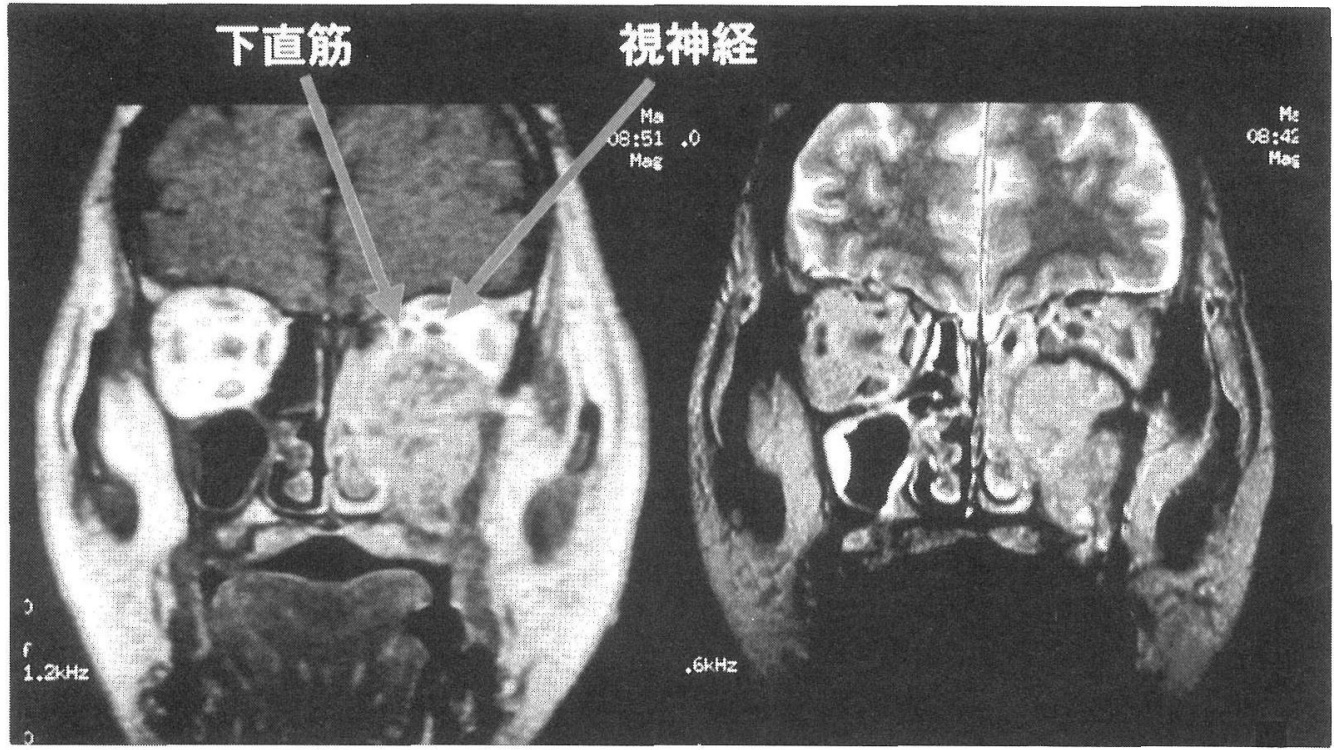

A

B

図 2 副鼻腔 MRI 所見

A. 造影 $\mathrm{T} 1$ 強調画像 : 左上顎洞から眼窩内へと至る造影剂により内部が不均一に造影された腫瘤陰影 を認めた。篩骨洞内はやや高信号で, 腫瘤の進展というよりも慢性副鼻腔炎の存在を疑わせた。また 下直筋，視神経は腫瘤により著明に压排されていたが，腫瘤の浸潤はないようであった。

B. T2 強調画像 : 腫瘤内部は不均一な等〜高信号を示し, 眼窩底〜上顎洞内側壁にかけ, 低信号領域 を認め，骨膜の残存を疑わせた。

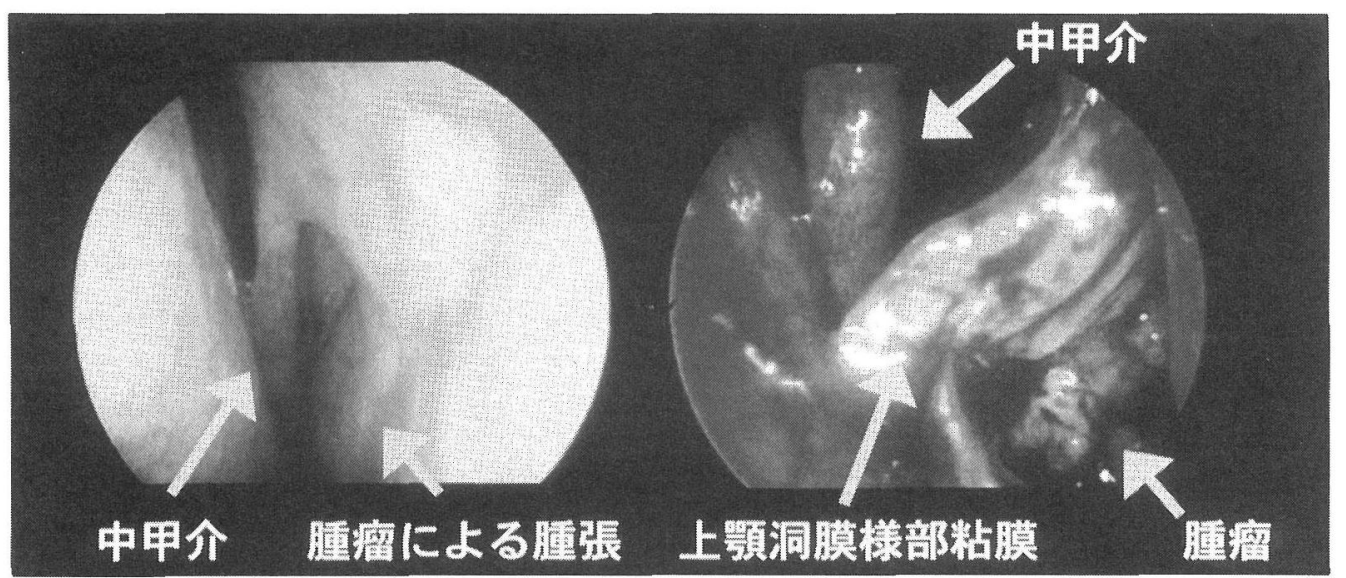

図 3 内視鏡下生検時所見

鼻腔内には腫瘤の浸潤はなく, 粘膜も正常であり, 膜様部の膨隆を認めるのみであった. 膜様部を切 開すると，内部には灰白色の腫瘤が充満していた。

にノミにて前壁を開空したところ, 骨の肥厚は著しく, 厚さは $5 \sim 6 \mathrm{~mm}$ ほどあった。 そして前回の生検時と同 様，洞内には灰白色の肉芽様腫瘤が充満していた。腫瘤
は後上壁，眼窩底で強く癒着していたが，骨膜下に剥離 することができた。また眼简底では骨はほぼ吸収されて いたが骨膜は存在しており，腫瘤は眼简内には浸潤して 


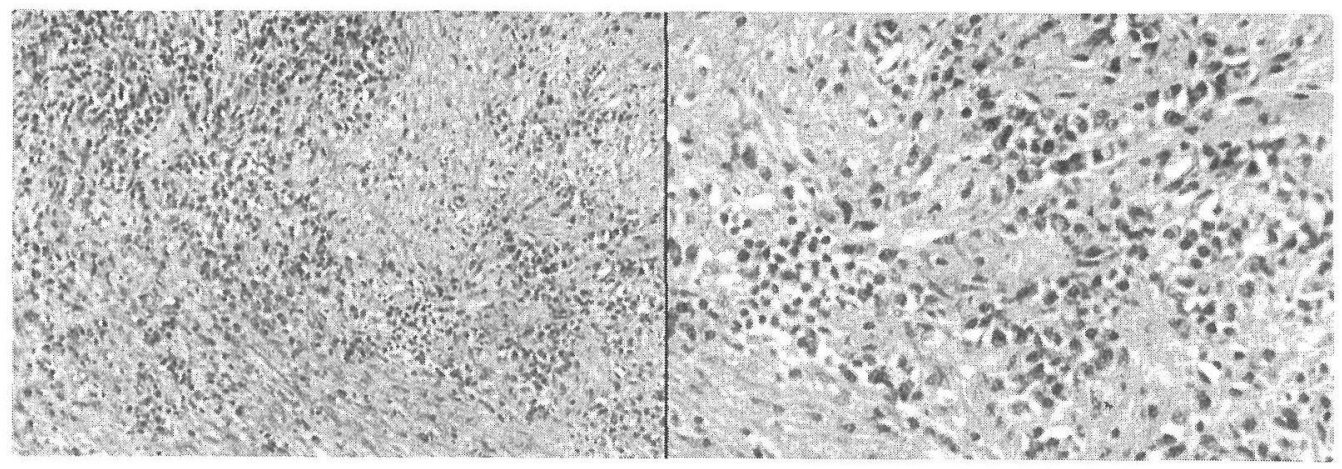

A

B

図 4 病理組織所見 (HE 染色. A : 25 倍, B : 50 倍)

線維芽細胞の増生を背景にリンパ球，形質細胞の強い浸潤を認める慢性炎症性肉芽のみであり，一部 に多核巨細胞，好中球の浸潤が散見される膿瘍部分と出血巣を認めた。

いなかった。 そして piece by piece に腫瘤を全摘出し，上 顎洞自然口を大きく開空して手術を終了した。出血量は 約 $60 \mathrm{ml}$ であった。

摘出標本による病理組織学的所見では腫瘍細胞は全く 認めず, 線維芽細胞の増生を背景にリンパ球, 形質細胞 の強い浸潤を認める慢性炎症性肉芽のみであり，一部に 多核巨細胞好中球の浸潤を認める膿場と出血巣を認め た。このことから炎症性偽腫瘍 (inflammatory pseudotumor）と診断された（図 4)。

術後, 眼球突出, 流涙, 内転障害は改善し, また視力 障害, 視野障害なども出現しなかった。

以後，特に自覚的症状はなかったが，平成 12 年 6 月の 副鼻腔 CT にて上顎洞に再発を認め, 7 月 21 日再入院と なった。 7 月 25 日, 局所麻醉下で Denker 氏法に準じた 腫瘤摘出術を行った。腫瘤は上顎洞を充満し，一部は前 回開放した自然孔より突出していた。前回の手術所見と 同様，眼窩底の骨膜は残存していたものの，腫瘤との癒 着は強く剥離は困難で, 眼球運動を確認しつつ可及的に 肉芽を鉬除した。そして，下鼻甲介，中鼻甲介を含め上 顎洞内側壁を切除し手術を終了した。

摘出標本による病理組織学的所見は，今までと同様壊 死組織が多く炎症所見が強いものであったが，前回と異 なる点は, 形質細胞, 組織球などの炎症細胞に混じって 大型のリンパ球が目立つことであった．短期間に再発し ていることなどから nasal NK/T cell lymphoma の可能性 も否定できず， T 細胞系の免疫染色も行ったが，やはり 単なる炎症, またはウェゲナー肉芽腫などの類縁疾患と
のことであった。

今回の入院中, 呼吸器, 腎機能や自己抗体などの精查 ももら一度行ったが，気管支喘息による 1 秒率の低下以 外，特に異常所見はなかった。

手術より 8 日後にパッキングガーゼの全抜去を行った が, 上壁にはすでに一部肉芽がみられたため, 外来通院 にてリンデロン懸濁液の局注を行らこととし，8月 7 日 退院となった。

以後外来通院にて，硬性内視鏡を用いて肉芽にリンデ ロン懸濁液 $2.5 \mathrm{mg}$ を局注する治療を 1 週間に 1 度行っ た. 5 カ月経過した平成 12 年 12 月の副鼻腔 CT では腫榴 の残存は認めるものの特に増大傾向ないため, 局注は 2 週間に 1 度へと減量した。ささらに定期的な経過観察の CT でも增大を認めないため, 平成 13 年 3 月からは 3 週間に 1 度とした。 しかし 6 月頃より左眼窩部の痛みが出現,さ らには7月に入り左複視が出現し, 眼球突出も著明となっ てきたため副鼻腔 $\mathrm{CT}$ ，MRI を施行したところ，腫瘤の 增大認め, 減量術目的にて平成 13 年 7 月 24 日当科入院 となった。

平成 13 年 7 月 26 日，局所麻酔下に手術を行った。 前 回の歯肉部の切開線に沿って上顎洞内へとアプローチ し，腫瘤を上顎洞下壁から側壁に沿って剥離した。眼简 底はやはり癒着がひどく可及的に鈍的に剥離した。.今回 は上顎洞後壁む骨欠損しており, 可及的に剥離した後, 同部位をKTP レーザーにて焼灼した。

なお，今回の摘出標本でも病理診断は炎症性偽腫瘍で あった。 
術後，左眼球突出，上方視での複視は消失したものの 下方視での複視は改善しなかった. パッキングガーゼの 全抜去後，上顎洞内には著明な肉芽は認めず，平成 13 年 8 月 3 日退院となった。現在術後 6 力月が経過し, 外来 での硬性内視鏡下の観察では肉芽の増大は認めていない が，今までの経過からみて今後も厳重な観察が必要と考 えられる。

\section{考 察}

炎症性偽腫瘍（inflammatory pseudotumor）は，線維芽 細胞の増生を背景に, リンパ球，形質細胞，組織球など の強い浸潤を伴った非腫瘍性の慢性炎症性肉芽であ る ${ }^{1)}$. しかし臨床的には腫瘍性に発育し腫瘤形成するこ とから，悪性腫瘍との鑑別は困難なことが多く，実際多 くの報告でも悪性を疑い，生検あるいは手術標本での病 理組織診断で最終診断されている21.

炎症性偽腫瘍は，初めは肺に発生する非腫瘍性腫瘤と して報告された ${ }^{3)}$. しかし，その後肺だけでなく，腎臟， 脾臟，胃，肝臟などさまざまな臓器において発生が報告 されており 4) 7), 頭頸部領域でも頭蓋内, 眼窩, 喉頭, 副咽頭間隙，扁桃，甲状腺などでの報告がある ${ }^{8)}$ 13). 副 鼻腔での発生はまれではあるが何例か報告されており 2)14) 19), 今症例のように悪性腫瘍との鑑別が問題となっ ている.

副鼻腔，特に上顎洞は扁平上皮癌などの癌腫だけでな く，悪性リンパ腫や髄外性形質細胞腫などの造血系悪性 腫瘍，キャッスルマン病や以前は進行性鼻壊疽の範疇で 捉えられていたウェダナー肉芽腫などの自己免疫疾患の 発生もみられるなど, 病理組織学的な確定診断が困難な こともある。

実際, 本症例でも最後まで悪性リンパ腫, 特に nasal NK/T cell lymphoma との鑑別に苦慮した。一般に悪性り ンパ腫は monoclonal に増殖することを特徴とし，その診 断では HE 染色による monoclonal な異型リンパ球の増殖 の確認と免疫染色によるリンパ球（特に免疫グロブリン 軽鎖）の monoclonality の証明が必要であるが，鼻副鼻腔 に多く発生する悪性リンパ腫nasal NK/T cell lymphomaの 場合，かつて polymorphic reticulosis といわれていたよう に, リンパ球の polymorphous な增殖が多くみられ，その 他, 形質細胞, 組織球に混じって大型の単核・多核細胞 など多彩な組織像を示し, HE 染色のみでは鑑別は困難 である ${ }^{20)}$.また REAL 分類での angiocentric lymphoma で
は血管破壊性に進展し，炎症・壊死組織を多く含むこと から，生検などで炎症性肉芽や壊死組織しか検出できな いことが多いとされている21).

また髄外性形質細胞腫についても，形質細胞の monoclonalな增殖, 特に免疫グロブリン軽鎖の monoclonalityの 証明が決め手となるが，こちらの場合線維芽細胞の増生 をあまり伴わないことや, 血清, 尿中の免疫グロブリン, Bence-Jones 蛋白の検出などの特徵があり比較的鑑別は 容易だが，髄外性の場合それらを欠くものも多いとの報 告もある ${ }^{22}$.

本症例では, 胸部 X 線写真, 腎機能などに異常はなく, また血液検査でも血沈，CRP も正常範囲で，自己抗体は c-ANCA，p-ANCA，RF，ANA などいずれも陰性であった ことから，ウェグナー肉芽腫は否定的と考えられた。

このような背景や短期間での度重なる再発からも, 複 数の病理医を交えて慎重に検討したが，全体の摘出病理 標本を詳細に検索しても腫瘍細胞が全く認められないこ とと，その他の臨床的な所見とを総合的に合わせて，炎 症性偽腫瘍との診断に至った。

炎症性偽腫瘍（inflammatory pseudotumor）は別名 plasma cell granuloma ともいわれ, 肺に発生するものが最 も多い，肺以外にも多く発生するが，肺外性のものは肺 発生のものと性格を異にするとの報告もあり ${ }^{23)}$ ，果たし てすべてのものが病理組織学的に炎症性偽腫瘍という一 つのカテゴリーに属するのか異論のあるところである.

実際，上顎洞に発生する炎症性偽腫瘍は，病理学的に 単一でないとの意見もあり ${ }^{15)}$ ，除外診断的な側面がある ことも事実であるが，現在のところ WHO の分類では単 一の病理組織学的疾患として扱われている. また本邦で は以前より田所 ${ }^{24)}$ の提唱したいわゆる「血瘤腫」という 疾患概念があり，炎症性偽腫瘍はそれと一部重なる部分 があると考えられる。しかし病理組織上，炎症性偽腫瘍 はあくまで炎症と慢性肉芽を中心とし，形質細胞などの 炎症性細胞の浸潤と壊死組織を中心とするのに対し，一 方で「血瘤腫」では出血の反復による毛細血管の拡張, 槐血，増生に対し，炎症性細胞が浸潤した像が典型例で ある25)．また画像所見などで，「血瘤腫」の場合，腫瘤の 周囲に MRI T2 強調画像にて高信号な部分がみられ，こ れが画像的な特徴とされるが 26277，炎症性偽腫瘍の場合 は画像上，不均一な腫瘤を形成するなど違いもみられ る ${ }^{16)}$. しかし「血瘤腫」自体がその概念として複数の病 理組織疾患を包合していることから，それら矛盾も妥当 
なことと考えられる.

またその発生原因であるが，肺の炎症性偽腫瘍では， 多くはウイルス性肺炎の既往があり，それに続発してい ることがほとんどであるとされている ${ }^{28)}$. しかし上顎洞 発生のものでは, 症例数が少なく統一的な見解はない. 一方，「血瘤腫」では尾崎ら ${ }^{29)}$ によると血管腫，感染，外 傷などによる反復した出血，炎症が誘因と考えられてお り，やはり感染が何らかの原因となっているのではない かと思われる. 本症例では歯科治療の既往があり, CT に ても歯根部から上顎洞内に一部瘦孔が連続しているよう な像があり，これらから考えると慢性的な歯性上顎洞炎 から発生したのではないかと推測されるが，原因ははっ きりとはしなかった。

治療については,一般には外科的摘出が第 1 とされる. しかし肺の炎症性偽腫瘍における長期観察例で, 悪性化 した例がなかったことなどから ${ }^{30)}$ ，生検にて診断が確定 し, 臨床的症状がない場合, 保存的に様子をみてもよい との意見もある，一方，上顎洞に発症した場合，増大に 伴いその解剖学的位置より本症例のように鼻閉, 眼球突 出, 眼球運動障害, 煩部腫脹などの症状を示すことから, 外科的摘出が第 1 と考える．今症例ではたび重なる再発 の治療に対して難橴したが, 特に眼窩底部の病栄に対し ては過度の切除による機能障害などを避けるため, 可及 的に腫瘤を剥離した後, KTP レーザーで燒灼するなど工 夫を行った．また術後は外来にて硬性内視鏡下に副腎皮 質ステロイドホルモンの局所投与を行い効果があったと 考えられる. その他, 文献的には再発例に対して, 放射 線治療を行った報告19) や副腎皮質ステロイドの全身投与 の報告17311)もあり，考慮すべき方法と考えられた。

\section{まとめ}

1）上顎洞に発生した炎症性偽腫瘍症例を報告した。

2）上顎洞の骨破壊を伴う腫瘤性病変を考える時, 悪性 腫瘍やウェゲナー肉芽腫とともに炎症性偽腫瘍は鑑別す べき疾患の一つであると考えられた。

3）治療については一般には外科的摘出が一般的とさ れるが，再発例に対しては放射線治療や本症例のような 副腎皮質ステロイドホルモンの局所投与も効果的と考え られた。

\section{謝辞}

本稿を終えるにあたり，本症例の検討・病理診断に御指導を
頂きました住友病院病理部主任部長 辻村崇浩先生に深謝致し ます。

本論文の要旨は日本耳鼻咽喉科学会第 273 回大阪地方連合会 例会（平成 12 年 6 月, 大阪）において口演した。

\section{参考文献}

1) Shanmugaratnam $K:$ WHO Histological typing of tumor of the upper respiratory tract and ear. Second Edition. pp 77, Springer-Verlag, Heidelberg, 1993.

2) Weisman RA and Osguthorpe JD : Pseudotumor of the head and neck masquerading as neoplasia. Laryngoscope 98:610 614, 1988.

3) Bahadori $M$ and Liebow $A$ : Plasma cell granulomas of the lung. Cancer 31: $191 \sim 208,1973$.

4) Itoh $H$, Namiki $M$, Yoshioka $T$, et al. : Plasma cell granuloma of the renal pelvis. J Urol $127: 1177 \sim 1178,1982$.

5) Cotelingam J and Jaffe ES : Inflammatory pseudotumor of the spleen. Am J Surg Pathol $8: 375 \sim 380,1984$.

6) Isaacson $P$, Buchanan $R$ and Mepham BL : Plasma cell granuloma of the stomach. Hum Pathol $9: 355 \sim$ 358, 1978.

7) Horiuchi R, Uchida T, Kojima T, et al. : Inflammatory pseudotumor of the liver; clinicopathologic study and review of the literatur. Cancer $65: 1583 \sim 1590,1990$.

8) Gangemi M, Maiuri F, Giamundo A, et al. : Intracranial plasma cell granuloma. Neurosurgery $24: 591 \sim 595,1989$.

9) Garner A : Pathology of pseudotumours' of the orbit; a review. J Clin Pathol $26: 639 \sim 648,1973$.

10) Albizzati $C$, Ramesar $K C$ and Davis $B C$ : Plasma cell granuloma of the larynx (case report and review of the literature). J Laryngol Otol $102: 187 \sim 189,1988$.

11) Hytiroglou P, Brandwein MS, Strauchen JA, et al. : Inflammatory pseudotumor of the parapharyngeal space; case report and review of the literature. Head Neck $14: 230 \sim 234,1992$.

12) Weilbaecher TG and Sarma DP : Plasma cell granuloma of the tonsil. J Surg Oncol $27: 228 \sim 231,1984$.

13) Yapp R, Linder J, Schenken JR, et al. : Plasma cell granuloma of the thyroid. Hum Pathol $16: 848 \sim 850,1985$.

14) Takimoto $T$, Kathoh $T$, Ohmura $T$, et al. : Inflammatory pseudotumor of the maxillary sinus mimicking malignancy. Rhinology $28: 123 \sim 127,1990$.

15) Batsakis J, el-Naggar AK, Luna $M$, et al. : "Inflammatory pseudotumor" what is it? How does it behave? Ann Otol Rhinol Laryngol $104: 329 \sim 331,1995$.

16) Som PM, Brandwein MS, Maldjian C, et al. : Inflammatory pseudotumor of the maxillary sinus; CT and MR findings in six cases. AJR Am J Roentgenol 163 : $689 \sim 692,1994$.

17) Maldjian JA, Norton KI, Groisman GM, et al. : Inflammatory 
pseudotumor of the maxillary sinus in a 15 -year-old boy. AJNR Am J Neuroradiol $15: 784 \sim 786,1994$.

18) Muzaffar M, Hussain SI and Chughtai A : Plasma cell granuloma; maxillary sinuses. J Laryngol Otol 108:357 358, 1994.

19) Ktaili M, Al-Masri $\mathrm{N}$ and Williams RC Jr : Wegener's lookalike. J Rheumatol $25: 180 \sim 182,1998$.

20）青笹克之, 美島健二, 古謝静男 : 鼻領域の悪性リンパ腫と 類縁疾患. 病理と臨床 $11: 1410 \sim 1414,1993$.

21) Hatta C, Ogasawara H, Okita J, et al. : Non-Hodgkin's malignant lymphoma of the sinonasal tract; treatment outcome for 53 patients according to REAL classification. Auris Nasus Larynx $28: 55 \sim 60,2001$.

22）志藤文明, 森本賢治, 三部重雄, 他 : 咽頭に原発した IgA$\kappa$ 型髄外性形質細胞腫. 日耳鼻 $84: 837 \sim 849,1981$.

23) Meis $J$ and Enzinger $F$ : Inflammatory fibrosarcoma of the mesentery and retroperitineum. Am J Surg Pathol 15:1146 1156, 1991.

24）田所喜久馬：上顎洞血瘤二就イテ. 大日本耳鼻 $23: 359$ $365,1917$.

25）宮地 徹, 斉藤 脩: 14. 血瘤腫. 病理カラーアトラス 耳鼻咽喉科領域の病理. $86 \sim 87$ 頁, 杏林書院, 東京, 1992 .
26）松田圭二, 山崎正幸, 森 満保, 他：上顎洞血瘤腫診断に おける MRI の有用性. 日鼻 $42: 1072 \sim 1075,1996$.

27）奥窪明子, 石田春彦, 天津睦郎, 他：上顎洞血瘤腫の術前 画像診断. 耳喉頭頸 $70: 35 \sim 38,1996$.

28) Spencer $H$ : The pulmonary plasma cell/histiocytoma complex. Histopathology $8: 903 \sim 916,1984$.

29）尾崎正義, 酒井俊一, 池田 寛: 鼻腔-副鼻腔血瘤腫 25 例. 耳喉 $49: 53 \sim 58,1977$.

30) Berardi RS, Lee SS, Chen HP, et al. : Inflammatory pseudotumours of the lung. Surg Gynecol Obstetr $156: 89 \sim 96$, 1983.

31) Fradis M, Rosenman D, Podoshin L, et al. : Steroid therapy for plasma cell garanuloma of the larynx. Entechnology 67:558 564, 1988.

原稿受付 : 平成 14 年 3 月 26 日

原稿採択：平成14年 4 月 24 日

別刷請求先 : 中川 崇

于565-0871 吹田市山田丘2-2

大阪大学大学院医学研究科臓器制御医学感覚器外科 学耳鼻咽喉科〈E8 